\title{
$\frac{100}{\text { WT }}$ RPEiS
}

\section{PRAWO DO EMERYTURY A ŚWIADCZENIE PIELĘGNACYJNE - SPORY I KONTROWERSJE}

\section{WPROWADZENIE}

Zgodnie z treścią art. 17 ust. 1 ustawy z 23 listopada 2003 r. o świadczeniach rodzinnych ${ }^{1}$, świadczenie pielęgnacyjne przysługuje $z$ tytułu rezygnacji $\mathrm{z}$ zatrudnienia lub innej pracy zarobkowej w związu z opieką nad osobą legitymujacca się orzeczeniem o znacznym stopniu niepełnosprawności albo orzeczeniem o niepełnosprawności łącznie ze wskazaniami: konieczności stałej lub długotrwałej opieki lub pomocy innej osoby w związku ze znacznie ograniczoną możliwością samodzielnej egzystencji oraz konieczności stałego współudziału na co dzień opiekuna dziecka w procesie jego leczenia, rehabilitacji i edukacji. W literaturze trafnie przyjmuje się, że celem świadczenia pielęgnacyjnego jest udzielenie materialnego wsparcia osobom, które rezygnują z aktywności zawodowej, by opiekować się osobą niepełnosprawna. Świadczenie pielęgnacyjne ma zatem zastapić dochód wynikający ze świadczenia pracy, której nie może podjać osoba pielęgnująca. Istota świadczenia pielęgnacyjnego jest więc częściowe zrekompensowanie opiekunowi niepełnosprawnego strat finansowych spowodowanych niemożnością podjęcia pracy lub rezygnacją z niej w związku z koniecznością opieki nad osobą niepełnosprawną ${ }^{2}$.

Celem artykułu jest dokonanie analizy przepisów prawa oraz praktyki sądowej w aspekcie tego, w jaki sposób ustalone prawo do emerytury wpływa na możliwości nabycia prawa do świadczenia pielęgnacyjnego. Za główny cel niniejszego artykułu przyjęto przedstawienie różnorodnej wykładni przepisu art. 17 ust. 5 pkt 1 lit. a u.ś.r. prezentowanej w orzecznictwie sądów admini-

\footnotetext{
Adrianna Szczechowicz, Uniwersytet Warmińsko-Mazurski w Olsztynie, adrianna.szczechowicz@uwm.edu.pl, https://orcid.org/0000-0001-6598-2103.

1 T.jedn.: Dz. U. 2020, poz. 111 ze zm. (dalej jako: u.ś.r.).

${ }^{2}$ Por. Kawecka (2015).
} 
stracyjnych. Mając na względzie odwrócenie relacji ekonomicznych świadczenia pielęgnacyjnego i emerytury, należy przede wszystkim odpowiedzieć na pytanie, czy aktualne regulacje prawne sa wystarczające w tym zakresie, czy też należy je znowelizować. Dotychczasowa praktyka stosowania tego przepisu wskazuje, że możemy wyodrębnić trzy różne stanowiska orzecznicze w tej kwestii:

1) pogląd wyłączający prawo do świadczenia pielęgnacyjnego osobie pobierającej emeryturę;

2) pogląd wyłączający prawo do świadczenia pielęgnacyjnego osobie pobierającej tylko do wysokości otrzymywanej emerytury;

3) pogląd dopuszczający możliwości przyznania osobom spełniającym warunki do otrzymania świadczenia pielęgnacyjnego, a pobierającym emeryturę jedynie w przypadku dokonania przez osobę uprawnioną wyboru jednego z tych świadczeń (tj. świadczenia pielęgnacyjnego).

\section{POGLĄD WYLĄCZAJĄCY PRAWO DO ŚWIADCZENIA PIELĘGNACYJNEGO OSOBIE POBIERAJĄCEJ EMERYTURĘ}

Do 2019 r. w orzecznictwie niemal powszechnie prezentowany był pogląd, że art. 17 ust. 5 pkt 1 lit. a u.ś.r. wprost wyłącza prawo do świadczenia pielęgnacyjnego osobie sprawującej opiekę, która ma ustalone prawo do emerytury. Przepisy powołanej ustawy nie umożliwiaja przy tym miarkowania, czy też uwzględniania szczególnej sytuacji finansowej bądź rodzinnej wnioskodawcy, zakładając, że w każdym przypadku nie jest możliwy zbieg świadczeń emerytalnego i świadczenia pielęgnacyjnego ${ }^{1}$.

$\mathrm{W}$ orzecznictwie zwrócono uwagę, że nie została przewidziana w art. 17 ust. 5 pkt 1 lit. a u.ś.r. możliwość ustalenia prawa osoby sprawującej opiekę nad osobą niepełnosprawną do świadczenia pielęgnacyjnego w wysokości co najmniej różnicy pomiędzy obecnie obowiąująca wysokością świadczenia pielęgnacyjnego a otrzymywaną przez nią emeryturą. Naczelny Sąd Administracyjny uznawał, że przyjęcie stanowiska dopuszczającego przyznanie świadczenie pielęgnacyjne w wysokości różnicy pomiędzy jego wysokością a wysokościa otrzymywanej emerytura oznaczałoby naruszenie zasady praworządności wyrażonej w art. 7 Konstytucji RP, wymagającej przestrzegania prawa zarówno przez obywateli, jak i organy administracji. Wypłata tak rozumianej różnicy powoduje bowiem dalsze komplikacje, w szczególności pozostaje w sprzeczności z treścią art. 17 ust. 3 u.ś.r., który wysokość świadczenia pielęgnacyjnego określa kwotowo. Naczelny Sąd Administracyjny jednolicie przyjmował, że wykładania literalna tego przepisu jest jasna i nie budzi wątpliwości, jednakże wymaga kontynuacji wykładni na podstawie dyrektyw wykładni celowościowej i systemowej. Przyjmował, że celowo ustawodawca zdecydował wyłą-

${ }^{1}$ Wyrok NSA z 10 marca 2017 r., I OSK 2573/15, Legalis nr 1631937. 
czyć z kręgu podmiotów uprawnionych do świadczenia pielęgnacyjnego osoby, które mają już ustalone prawo do emerytury, nie pozostaja one bowiem bez pomocy ze strony państwa $\mathrm{z}$ tytułu rezygnacji z pracy ze względu na sprawowanie opieki nad osobą niepełnosprawna. Zatem osobie opiekującej się osobą niepełnosprawną zrekompensowano już częściowo stratę finansową z uwagi na wcześniejszą rezygnację z aktywności zawodowej². Uzasadniając to stanowisko, NSA wskazywał, że świadczenie emerytalne nawet w niższej wysokości niż świadczenie pielęgnacyjne jest świadczeniem pewnym i stabilnym. Natomiast świadczenie pielęgnacyjne niestanowiące elementu systemu zabezpieczeń społecznych takim pewnym i stabilnym świadczeniem nie jest, a zatem świadczenie emerytalne $\mathrm{w}$ dalszej perspektywie jest świadczeniem korzystniejszym $^{3}$.

Stanowisko to jest zgodne z tzw. zasadą pomocniczości, w świetle której świadczenia z pomocy społecznej nie powinny być „stawiane” przed świadczeniami z ubezpieczenia społecznego. Ponadto konkretny rodzaj ryzyka (w przypadku świadczenia pielęgnacyjnego - ryzyka niesamodzielności) może być chroniony tylko jednym świadczeniem, nawet gdy świadczenia wywodzą się z różnych systemów ${ }^{4}$.

Naczelny Sąd Administracyjny odwołał się przy tym do konstytucyjnych zasad wyrażonych $\mathrm{w}$ art. $2 \mathrm{i}$ art. 32 , stwierdzając, że przyznanie osobie, posiadającej już swego rodzaju rekompensatę z tytułu rezygnacji z pracy świadczenia pielęgnacyjnego stanowiłoby naruszenie tych przepisów, otrzymywałaby ona bowiem wówczas dwa świadczenia z tego samego tytułu i tym samym znajdowałaby się w korzystniejszej sytuacji od osób, które już nie mają możliwości przejścia na wcześniejszą emeryturę

W obszernym uzasadnieniu WSA we Wrocławiu, stwierdził, że trudna sytuacja materialna i pobieranie w niższej wysokości niż świadczenie pielęgnacyjne emerytury nie może przemawiać za przyznaniem świadczenia pielęgnacyjnego, zważywszy na wyraźny przepis ustawy, który takiej przesłanki nie wprowadził. Nie jest możliwy zatem zbieg obu tych świadczeń ani ich wzajemna kompensata. Przede wszystkim Sąd słusznie zauważył istotę powstałego problemu - brak regulacji przewidującej zasadę przyznawania wnioskodawcy świadczenia o najwyższej kwotowo wysokości (świadczenia pielęgnacyjnego) z równoczesnym zawieszeniem prawa do niższego kwotowo świadczenia (emerytury), czy też wstrzymania wypłaty niższego kwotowo świadczenia oraz regulacji wskazującej, czy organ jest związany żądaniem strony w zakresie wnioskowanego świadczenia (jako najkorzystniejszego), czy też, że to organ z urzędu ocenia, które ze świadczeń jest dla wnioskodawcy najbardziej korzystne $e^{6}$.

\footnotetext{
2 Wyrok NSA z 10 lipca 2018 r., I OSK 134/18, Legalis nr 1867387.

${ }^{3}$ Wyrok NSA z 6 kwietnia 2017 r., I OSK 2950/15, Legalis nr 1605218.

${ }^{4}$ Lewandowicz-Machnikowska (2019): 38-39.

${ }^{5}$ Wyrok NSA z 10 lipca 2018 r., I OSK 134/18, Legalis nr 1867387.

${ }^{6}$ Wyrok WSA we Wrocławiu z 22 maja 2019 r., IV SA/Wr 105/19, Lex nr 2695689
} 


\section{POGLĄD WYLĄCZAJĄCY PRAWO DO ŚWIADCZENIA PIELĘGNACYJNEGO OSOBIE POBIERAJĄCEJ TYLKO DO WYSOKOŚCI OTRZYMYWANEJ EMERYTURY}

Tak ukształtowany (dominujący) omówiony powyżej pogląd był przyjmowany zarówno w orzecznictwie ${ }^{7}$, jak i doktrynie ${ }^{8}$. Spór wynikną na kanwie nowej linii orzeczniczej dotyczącej wykładni art. 17 ust. 5 pkt 1 lit. a u.ś.r zapoczątkowanej wyrokiem WSA w Gorzowie Wielkopolskim z 20 lutego 2019 r. ${ }^{9}$ W orzeczeniu tym stwierdzono, że narusza zasadę równości taka wykładnia wskazanego przepisu, która pozbawia w całości prawa do świadczenia pielęgnacyjnego osoby mające ustalone prawo do emerytury w wysokości niższej niż to świadczenie. Z uzasadnienia wyroku WSA w Gorzowie Wielkopolskim wynika, że poprzestając jedynie na literalnym brzmieniu tego przepisu, przyjąć należy, iż osobie, która ma ustalone prawo do emerytury, nie przysługuje świadczenie pielęgnacyjne w jakiejkolwiek wysokości. Mimo że wykładnia językowa prowadzi do takiego wniosku, to jednak zdaniem Sąu zastosowanie dyrektyw wykładni systemowej oraz dyrektyw wykładni funkcjonalnej i celowościowej prowadzi do takiego rozumienia tego przepisu, że wyłącza on prawo do świadczenia pielęgnacyjnego osoby mającej ustalone prawo do emerytury nie w całości, ale do wysokości tej emerytury.

Ocena przedstawionego stanowisko wymaga odpowiedzi na pytanie, czy dyrektywy funkcjonalne i systemowe moga prowadzić do odrzucenia rezultatów wykładni językowej nawet w tych sytuacjach, gdy wykładnia językowa prowadzi do rezultatów jednoznacznych. Należy podzielić, wyrażany zarówno $\mathrm{w}$ literaturze $\mathrm{e}^{10}$, jak i judykaturze ${ }^{11}$, pogląd o dopuszczeniu stosowania analogii właśnie w przypadku, gdy literalne stosowanie prawa prowadzi do jego sprzeczności z fundamentalnymi zasadami konstytucyjnymi, do rozstrzygnięcia, które w świetle powszechnie akceptowalnych wartości pozostaje rażąco niesłuszne, niesprawiedliwe bądź nieracjonalne. Nawet zatem jeżeli rezultat wykładni językowej wydaje się jasny, należy, po pierwsze, kontynuować wykładnię i po drugie, w razie konfliktu dać pierwszeństwo rezultatowi otrzymanemu wedle dyrektyw funkcjonalnych, jeśli rezultat językowy burzy podstawowe założenia o racjonalności prawodawcy, zwłaszcza o jego spójnym systemie wartości, co wiaże się z dopuszczeniem w tej sytuacji wykładni rozszerzajacej albo zwężającej ${ }^{12}$.

7 Wyrok WSA w Łodzi z 22 września 2017 r., II SA/Łd 485/17, Legalis nr 1681333.

${ }^{8}$ Kopania (2017); Sierpowska (2004): 162-165; Mrozek (2017): 168-170, Rozbicka-Ostrowska (2015): 390-391.

${ }^{9}$ II SA/Go 833/18, Lex nr 2630867, podtrzymanej w orzeczeniach m.in. wyrok WSA w Krakowie z 11 kwietnia 2019 r., III SA/Kr 137/19, Lex nr 2650442; wyrok WSA w Rzeszowie z 25 lipca 2019 r., II SA/Rz 676/19, Lex nr 2724052.

${ }^{10}$ Morawski (2010): 193 i 228; Zieliński (2017): 301; Płeszka (1997): 77; Preisner (2003): 243, Gutowski, Kardas (2017): 275.

${ }^{11}$ Uchwała NSA z 10 grudnia 2009 r., I OPS 8/09, Legalis nr 226254.

12 Zieliński (2009): 6-10. 
Jak słusznie wskazał Maciej Kondej, uwzględnienie w procesie wykładni prawa wartości konstytucyjnych jest konieczne nie tylko w takim zakresie, w jakim pozwala na to językowe brzmienie tekstu aktu normatywnego, lecz także w tych przypadkach, w których rozstrzygnięcie problemu na podstawie literalnie odczytywanego tekstu ustawy prowadziłoby do akceptacji rozstrzygnięcia niesłusznego, niezgodnego z aksjologia ustawodawcy implementowaną do systemu prawnego przez przepisy konstytucji. Możliwość odwołania się w procesie stosowania prawa do wartości postrzegać należy jako swego rodzaju zawór bezpieczeństwa, umożliwiający przeciwdziałanie sytuacji, gdy literalnie stosowane prawo staje się źródłem niesprawiedliwości (summum ius, summa iniuria $)^{13}$. Jasność przepisów może zależeć od wielu czynników i zmieniać się w czasie, a przepis jasny może okazać się wątpliwy w związku z wprowadzeniem nowych przepisów bądź istotnej zmiany sytuacji społecznej czy ekonomicznej, mimo że jego brzmienie nie uległo żadnej zmianie ${ }^{14}$.

W świetle powyższych rozważań w orzecznictwie wskazano, że za przyjęciem tego poglądu przemawia zmiana relacji między wysokością świadczenia pielęgnacyjnego a wysokością świadczeń, których pobieranie wyłącza prawo do świadczenia pielęgnacyjnego. Kiedy ustawodawca, uchwalając w 2003 r. u.ś.r., wyłączył możliwość przyznania świadczenia pielęgnacyjnego opiekunom, którzy maja prawo do określonych świadczeń, określił wysokość świadczenia pielęgnacyjnego na $420 \mathrm{zł}$ miesięcznie i była to kwota niższa niż ówczesna wysokość najniższej emerytury i innych świadczeń wyłączających prawo do świadczenia pielęgnacyjnego. Taka relacja utrzymywała się aż do 1 maja 2014 r., kiedy to świadczenie pielęgnacyjne wzrosło do 800 zł i stało się nieznacznie wyższe od najniższej emerytury, a następnie było waloryzowane i obecnie jest już znacznie wyższa od najniższej emerytury (wysokość świadczenia pielęgnacyjnego -1583 zł, wysokość najniższej emerytury -1100 zł $)^{15}$. Niewątpliwie zatem intencją ustawodawcy wprowadzającego to wyłączenie było, aby uprawniony opiekun nie pobierał świadczenia pielęgnacyjnego w sytuacji, gdy otrzymuje świadczenie wyższe. Jednakże odczytanie przepisu art. 17 ust. 5 pkt 1 lit. a u.ś.r. w obecnych realiach jako pozbawiającego w całości świadczenia pielęgnacyjnego także opiekuna otrzymującego świadczenie znacznie niższe wymagałoby jednoznacznego potwierdzenia przez dyrektywy wykładni systemowej oraz funkcjonalnej i celowościowej. Reasumując, ta istotna zmiana sytuacji spowodowała konieczność weryfikacji - wydawałoby się - jasnych rezultatów wykładni językowej art. 17 ust. 5 pkt 1 lit. a u.ś.r. zgodnie z regułami wykładni systemowej oraz celowościowej i funkcjonalnej ${ }^{16}$.

Powstaje pytanie, jak ocenić to rozwiązanie legislacyjne z punktu widzenia jego zgodności z konstytucyjnymi zasadami: równości wobec prawa (art. 32

13 Kondej (2019): 44.

14 Morawski (2002): 65.

15 Dane na rok 2019. W 2020 r. kwota świadczenia wynosi 1830,00 zł zgodnie z obwieszczeniem Ministra Rodziny, Pracy i Polityki Społecznej z 23 października 2019 r. (M.P. 2019, poz. 1067). Najniższa emerytura od 1 marca 2020 r. wynosi 1200 zł.

16 Wyrok WSA w Gorzowie Wielkopolskim z 20 lutego 2019 r., II SA/Go 833/18, Lex nr 2630867; wyrok WSA w Rzeszowie z 16 października 2019 r., II SA/Rz 828/19, Lex nr 2742445. 
ust. 1 Konstytucji), sprawiedliwości społecznej (art. 2 Konstytucji), obowiązku udzielania szczególnej pomocy rodzinom znajdującym się w trudnej sytuacji materialnej i społecznej (art. 71 ust. 1 zd. drugie Konstytucji) i osobom niepełnosprawnym (art. 69 Konstytucji).

W doktrynie wskazuje się, że sformułowana w art. 32 ust. 1 Konstytucji zasada jest lex generalis dla pozostałych norm konstytucyjnych dotyczących równości i ją konkretyzujących ${ }^{17}$. Pojęcie równości rozumieć należy jako przynależność danych podmiotów do tej samej klasy, którą wyróżniamy z punktu widzenia cechy uznanej za istotna, i nie jest tożsama z pojęciem identyczności ${ }^{18}$. Podkreśla się związek zasady równości z zasadami sprawiedliwości społecznej unormowanej w art. 2 Konstytucji, która wskazuje, że „równość jest pochodną sprawiedliwości” ${ }^{19}$. Zasady równości wobec prawa i sprawiedliwości społecznej w znacznym stopniu nakładają się na siebie, różnicowanie sytuacji prawnej podmiotów podobnych ma więc znacznie większe szanse uznania za zgodne z konstytucja, jeżeli pozostaje w zgodzie z zasadami sprawiedliwości społecznej lub służy urzeczywistnieniu tych zasad. Zostaje ono natomiast uznane za niekonstytucyjne, jeżeli nie znajduje podtrzymania w zasadzie sprawiedliwości społecznej ${ }^{20}$. Trybunał Konstytucyjny w uzasadnieniu wyroku z 21 października 2014 r. (K 38/13) w odniesieniu do zróżnicowania poziomu świadczeń pielęgnacyjnych dla opiekunów osób niepełnosprawnych wskazał, że ustawodawca jest obowiązany precyzyjnie ustalić racjonalne przesłanki, od których uzależni zróżnicowany poziom świadczenia, przyjmując za punkt wyjścia jednakowe traktowanie takich opiekunów ${ }^{21}$.

W orzecznictwie dodatkowo słusznie zauważono, że za zróżnicowaniem sytuacji opiekunów osób niepełnosprawnych polegajacym na pozbawieniu świadczenia pielęgnacyjnego tych z nich, którzy otrzymuja świadczenia niższe, wymienione $\mathrm{w}$ art. 17 ust. 5 pkt 1 lit. a u.ś.r., nie przemawia stan finansów państwa. Świadczy o tym wprowadzenie w ostatnich latach nowych programów przyznających w dużej skali świadczenia socjalne także osobom zamożnym (świadczenie wychowawcze, świadczenia z tytułu rozpoczęcia roku szkolnego) oraz zapowiedzi daleko idacego rozszerzenia takich programów w najbliższym czasie ${ }^{22}$. Należy zatem uznać, że zróżnicowanie sytuacji tych osób, polegające na wyłączeniu w całości prawa do świadczenia pielęgnacyjnego tych opiekunów, którzy mają ustalone prawo do jednego ze świadczeń wymienionych w art. 17 ust. 5 pkt 1 lit. a u.ś.r. w sytuacji, gdy to świadczenie jest znacznie niższe od świadczenia pielęgnacyjnego, nie znajduje podstaw ani racjonalnych przesłanek.

Należy zwrócić uwagę przede wszystkim na to, że celem świadczenia pielęgnacyjnego - jest w ogólniejszym wymiarze - częściowe uzupełnienie środków finansowych rodziny, która ponosi dodatkowe koszty związane z opieką nad

\footnotetext{
17 Garlicki (2002): 96-98;

18 Banaszak (2009): 176 n.; Tarno (2016): 220.

19 Masternak-Kubiak (2002): 123.

20 Orzeczenie TK z 3 września 1996 r., K 10/96, Legalis 10313.

21 Legalis nr 1073312; Wincenciak (2018): 295.

22 Wyrok WSA w Rzeszowie z 16 października 2019 r., II SA/Rz 828/19, Lex nr 2742445.
} 
osobami najbliższymi ${ }^{23}$. Beneficjentem świadczenia pielęgnacyjnego jest cała rodzina osoby niepełnosprawnej, jak również ona sama odnosi z niego realną korzyść, gdyż ma w ten sposób zapewniona możliwość stałej opieki bliskiej osoby i stałego z nią kontaktu ${ }^{24}$. Poprzez wypłatę świadczenia pielęgnacyjnego władza publiczna realizuje zatem nałożone na nią w Konstytucji obowiązki udzielania szczególnej pomocy rodzinom znajdującym się w trudnej sytuacji materialnej i społecznej oraz udzielania osobom niepełnosprawnym pomocy w zabezpieczaniu egzystencji, komunikacji społecznej, a w niektórych przypadkach także przysposobieniu do pracy.

Mając na względzie powyższe rozważania, w trzech ostatnich wyrokach ${ }^{25}$, przy odnotowaniu stanowiska odmiennego ${ }^{26}$, NSA stwierdził, że zachowanie zasad konstytucyjnych nastapi jedynie w sytuacji, w której osoba mająca prawo do emerytury otrzyma świadczenie pielęgnacyjne w wysokości różnicy pomiędzy jego wysokością a wysokością otrzymywanej emerytury. Jej sytuacja nie będzie bowiem wówczas korzystniejsza niż osoby nieposiadającej prawa do emerytury ani też mniej korzystna niż osoby otrzymującej wyłącznie emeryturę znacznie niższą niż świadczenie pielęgnacyjne. Osoba taka będzie potraktowana także sprawiedliwie, gdyż w lepszej sytuacji znalazłby się opiekun, który nie podjąły nigdy pracy zarobkowej w swoim życiu. W pełni uzasadnione jest stanowisko, które należy utrzymać, że wykładnia art. 17 ust. 5 pkt 1 lit. a u.ś.r. winna uwzględniać także kontekst historyczny pojawienia się tego przepisu w systemie prawa, który przesądza o konieczności zastosowania reguł wykładni systemowej i funkcjonalnej. Odczytanie znaczenia tego przepisu w obecnych realiach jako pozbawiającego w całości świadczenia pielęgnacyjnego także opiekuna otrzymującego świadczenie znacznie niższe pozostaje w sprzeczności z wynikami takiej wykładni.

W orzecznictwie sądów administracyjnych wskazuje się, że pośrednim potwierdzeniem słuszności tego rozwiązania są dwa projekty ustaw o zmianie ustawy o świadczeniach rodzinnych oraz niektórych innych ustaw ${ }^{27}$, w których proponowano zmianę art. 17 polegającą na tym, że świadczenie pielęgnacyjne przysługiwać miało w wysokości różnicy pomiędzy kwotą świadczenia pielęgnacyjnego a kwota pobieranych świadczeń wymienionych obecnie w art. 17 ust. 5 pkt 1 lit. a, pomniejszonych o zaliczkę na podatek dochodowy od osób fizycznych oraz składkę na ubezpieczenie zdrowotne ${ }^{28}$.

Słusznie WSA w Gorzowie Wielkopolskim ${ }^{29}$ podkreślił, że kilkuletnia bezczynność ustawodawcy w procedowaniu tych projektów, pomimo powięk-

${ }^{23}$ Wyrok z TK z 21 października 2014 r., K 38/13, Legalis nr 1073312.

${ }^{24}$ Wyrok TK z 18 listopada 2014 r., SK 7/11, Legalis nr 1092564.

${ }^{25}$ Wyroki NSA: z 28 czerwca 2019 r., I OSK 757/19, Lex nr 2724028; z 8 stycznia 2020 r., I OSK 2392/19, Lex nr 2767685; z 30 kwietnia 2020 r., I OSK 1546/19, Lex nr 3009452.

${ }^{26}$ Wyroki NSA: z 6 kwietnia 2017 r., I OSK 2950/15; z 20 kwietnia 2017 r., I OSK 3269/15

${ }^{27}$ Projekt rządowy z 13 marca 2015 r., <https://www.gov.pl/web/rodzina/bip-projekt-ustawy-o-zmianie-ustawy-o-swiadczeniach-rodzinnych-oraz-niektorych-innych-ustaw > i poselski z 4 listopada 2016 r. <http://www.sejm.gov.pl/Sejm8.nsf/druk.xsp?nr=1100>.

${ }^{28}$ Wyrok WSA w Rzeszowie z 16 października 2019 r., II SA/Rz 828/19, Lex nr 2742445.

${ }^{29}$ Wyrok WSA w Gorzowie Wielkopolskim z 20 lutego 2019 r., II SA/Go 833/18, Lex nr 2630867. 
szania się z upływem czasu różnic między wysokością świadczenia pielęgnacyjnego, a wysokością najniższych świadczeń wymienionych w art. 17 ust. 5 pkt 1 lit. a wymaga od sądu podjęcia próby racjonalnego wytłumaczenia tego zaniechania. Stwierdził, że sądy i organy, przyjmujacc, że prawodawca działa racjonalnie i zgodnie z Konstytucja, nie zakładają złej woli prawodawcy, czyli w tym przypadku intencji niesprawiedliwego pokrzywdzenia pewnej grupy opiekunów osób niepełnosprawnych, którzy otrzymują bardzo niskie świadczenia i przez to mają być całkowicie pozbawieni prawa do przysługujacego im znacznie wyższego świadczenia pielęgnacyjnego. Sąd dobitnie podkreślił, że jedynym sensownym wytłumaczeniem zaniechania ustawodawcy, który jest racjonalny i działa z poszanowaniem Konstytucji, a jednak nie zmienił treści art. 17 u.ś.r., jest to, że przepis ten nie wymaga pilnej nowelizacji, albowiem możliwa jest taka jego interpretacja, która nie będzie naruszać konstytucyjnych zasad równości wobec prawa i sprawiedliwości społecznej oraz realizować będzie obowiązki udzielania szczególnej pomocy rodzinom znajdujacym się w trudnej sytuacji materialnej i społecznej i osobom niepełnosprawnym. W konsekwencji sądy oraz organy zobowiązane są na podstawie art. 8 ust. 2 Konstytucji do bezpośredniego stosowania jej przepisów.

Poza racjami ściśle prawnymi oraz wykładnią literalna przepisu należy uwzględnić także racje humanistyczne i społeczne, które wynikają prawa międzynarodowego. Zgodnie z Konwencją o prawach osób niepełnosprawnych, sporządzoną w Nowym Jorku 13 grudnia 2006 r., ratyfikowaną przez Polskę 25 października 2012 r..$^{30}$, państwa strony uznają prawo osób niepełnosprawnych do odpowiednich warunków życia ich samych i ich rodzin, włączając w to odpowiednie wyżywienie, odzież i mieszkanie oraz prawo do stałego polepszania warunków życia, i podejmą odpowiednie kroki w celu zagwarantowania i popierania realizacji tych praw bez dyskryminacji ze względu na niepełnosprawność. Mając to na względzie, strony Konwencji zobowiązały się podjaćc odpowiednie kroki w celu zapewnienia osobom niepełnosprawnym i ich rodzinom żyjacym w ubóstwie dostępu do pomocy państwa w pokrywaniu wydatków związanych z niepełnosprawnościa, w tym wydatków na odpowiednie szkolenia, poradnictwo, pomoc finansową i tymczasową opiekę dająca wytchnienie stałym opiekunom ${ }^{31}$. W mojej ocenie przyjęta w wyrokach NSA wykładnia przepisów w pełni respektuje to zobowiązanie, zapewnia bowiem osobie niepełnosprawnej i jej rodzinie skuteczną ochronę socjalną na równych prawach z pozostałymi osobami.

Warto również w tym miejscu odnieść się do wyroku TK z 26 czerwca 2019 r. (SK 2/17), w którym orzeczono o niezgodności art. 17 ust. 5 pkt 1 lit. a ustawy z 28 listopada 2003 r. o świadczeniach rodzinnych w zakresie, w jakim stanowi, że świadczenie pielęgnacyjne nie przysługuje, jeżeli osoba sprawująca opiekę ma ustalone prawo do renty z tytułu częściowej niezdolności do pracy, $\mathrm{z}$ art. 71 ust. $1 \mathrm{zd}$. drugie w związku z art. 32 ust. 1 Konstytucji RP.

${ }^{30}$ Dz. U. 2012, poz. 1669; por. oświadczenie rządowe z 25 września 2012 r., Dz. U. 2012, poz. 1170 .

31 Ślebzak (2016): 1557 n.; Bartoszewicz (2014): 158 n. 
W uzasadnieniu orzeczenia podkreślono, że świadczenie pielęgnacyjne jest instrumentem realizowania obowiązku wyznaczonego w art. 71 ust. 1 zd. drugie Konstytucji. Ograniczenie możliwości pobierania świadczenia pielęgnacyjnego przez opiekuna, który ma ustalone prawo do renty z tytułu częściowej niezdolności do pracy, ale jednocześnie nie podejmuje pracy z uwagi na sprawowanie opieki nad niepełnosprawnym dzieckiem, stanowi przejaw niewłaściwej realizacji tego obowiązku. Wobec powyższego TK przyjął, że różnicowanie sytuacji prawnej osób rezygnujących z pracy w celu sprawowania opieki nad niepełnosprawnymi zgodnie z przyjętym przez ustawodawcę kryterium posiadania przez takie osoby ustalonego prawa do renty z tytułu częściowej niezdolności do pracy jest niedopuszczalne. Prowadzi ono bowiem do wyłączenia opiekunów-rencistów z kręgu podmiotów uprawnionych do świadczeń pielęgnacyjnych, pomimo że sytuacja faktyczna takich osób sprawujących opieke nad niepełnosprawnymi (gdy nie podejmują oni zatrudnienia, które mogli podjać przy jednoczesnym pobieraniu świadczenia rentowego) jest tożsama z sytuacją osób zdolnych do pracy, lecz rezygnujących z niej w celu opieki nad niepełnosprawnym dzieckiem. Jednocześnie TK dostrzegł, że realna wysokość renty z tytułu częściowej niezdolności do pracy może być zdecydowanie niższa niż wysokość świadczenia pielęgnacyjnego. W systemie świadczeń rodzinnych brak rozwiązana, które pozwoliłoby tę sytuację rozwiązać dzięki na przykład obniżeniu wysokości przyznanego świadczenia proporcjonalnie do wysokości pobieranej renty. Sprzeczna z zasadą równości jest jedynie sytuacja, gdy samo przyznanie prawa do takiej renty skutkuje odebraniem świadczenia.

$\mathrm{Na}$ uwagę zasługuje zdanie odrębne sędziego Mariusza Muszyńskiego, który zauważył, że źródło problemu w danym przypadku nie polega jednak na naruszeniu konstytucyjnych wolności i praw przez poszczególne przepisy prawne, ale na zwykłych, choć dość istotnych, niedoskonałościach konstrukcyjnych systemu zabezpieczenia społecznego w zakresie wsparcia opiekunów osób niepełnosprawnych. Mimo dostrzeżenia problemu prawnego to jego rozwiązanie, zdaniem autora stanowiska, nie należy do kompetencji TK, pomoc społeczna bowiem jest instytucją polityki społecznej państwa, której wyznaczanie kierunków należy przede wszystkim do organów władzy wykonawczej, a o prawnych formach jej realizacji decyduje ustawodawca. Reasumujac, problem opiekunów osób niepełnosprawnych mających ustalone prawo do renty z tytułu częściowej niezdolności do pracy miał charakter systemowy i związany z realizacją polityki społecznej państwa, a nie z naruszeniem konstytucyjnych wolności i praw.

W pełni podzielam pogląd sędziego Muszyńskiego, że zakresowy kierunek rozstrzygnięcia, odnoszący się do stanu faktycznego skarżącej, nie uwzględnia treści całego przepisu będącego podstawą rekonstrukcji kwestionowanej normy prawnej. Z kolei zakresowe orzeczenie przez TK niekonstytucyjności wobec części jednej z grupy podmiotów wskazanych literalnie w przepisie (gdyż nie wszystkich osób sprawujących opiekę) jest wyrazem naruszenia zasady równego traktowania pozostałych podmiotów wskazanych w tym przepisie. Wyrok TK zamiast realizować konstytucyjne wartości dotyczące zasady rów- 
ności i sprawiedliwości społecznej przyczynił się zatem do pogłębienia istniejących nierówności w całej grupie opiekunów osób niepełnosprawnych.

W mojej ocenie trudno nie odnieść wrażenia, że sądy i TK w wyżej wskazanych orzeczeniach, wbrew jasnej wykładni językowej, odwołują się do dyrektyw wykładni systemowej oraz dyrektyw wykładni funkcjonalnej i celowościowej, aby wydać rozstrzygnięcie sprawiedliwe i społecznie akceptowalne. Można zatem uznać, że sądy poprawiają i działają za biernego w tym zakresie ustawodawcę, który nie dostosował przepisów do zachodzących zmian, w szczególności nie uwzględnił faktu dysproporcji ekonomicznych między wysokością świadczeń.

\section{POGLĄD DOPUSZCZAJĄCY MOŻLIWOŚCI PRZYZNANIA OSOBOM SPEŁNIAJACYM WARUNKI DO OTRZYMANIA ŚWIADCZENIA PIELĘGNACYJNEGO, A POBIERAJĄCYM EMERYTURĘ JEDYNIE W PRZYPADKU DOKONANIA PRZEZ OSOBĘ UPRAWNIONA WYBORU JEDNEGO Z TYCH ŚWIADCZEŃ}

W orzecznictwie WSA w Poznaniu pojawił się pogląd, że przyznanie świadczenia w pełnej wysokości określonej w art. 17 ust. 3 u.ś.r. osobom spełniającym warunki do otrzymania świadczenia pielęgnacyjnego, a pobierającym emeryture jest jedynie możliwe pod warunkiem dokonania przez osobę uprawnioną wyboru jednego z tych świadczeń ${ }^{32}$.

Tym samym nie podzielił stanowiska wyrażonego w wyżej wskazanych orzeczeniach i wskazał, że wypłata różnicy między wysokością emerytury a wysokością świadczenia pielęgnacyjnego pozostaje w sprzeczności z treścia art. 17 ust. 3 u.ś.r., który wysokość świadczenia pielęgnacyjnego określa kwotowo. Zdaniem Sądu rozwiązanie to może powodować komplikacje w zakresie ustalania przez organ wysokości należnej wypłaty świadczenia. Uzasadniając swoje stanowisko, Sąd wskazał, że osoby pobierające świadczenie pielęgnacyjne i osoby pobierajace emeryture podlegają obowiązkowi ubezpieczenia zdrowotnego, z tym że osoby pobierajace świadczenie pielęgnacyjne wtedy, gdy nie podlegają obowiązkowi ubezpieczenia z innego tytułu ${ }^{33}$. Podstawą wymiaru składek na ubezpieczenie zdrowotne dla osób pobierajacych emeryture jest kwota emerytury (art. 81 ust. 8 pkt 2 u.ś.o.z.), a dla osób pobierających świadczenie pielęgnacyjne - kwota odpowiadająca wysokości świadczenia pielęgnacyjnego przysługującego na podstawie przepisów o świadczeniach rodzinnych (art. 81 ust. 8 pkt 9 b u.ś.o.z.). Sąd uznał, że w przypadku przyjęcia stanowiska, iż świadczenie pielęgnacyjne osobie pobierającej emeryturę przysługuje do wy-

32 Wyrok WSA w Poznaniu z 21 listopada 2019 r., II SA/Po 697/19, Lex nr 2750005.

33 Art. 66 ust. 1 pkt 16 ustawy z 27 sierpnia 2004 r. o świadczeniach opieki zdrowotnej finansowanych ze środków publicznych, t.jedn.: Dz. U. 2019, poz. 1373 ze zm. (dalej jako: u.ś.o.z.). 
sokości różnicy między tymi świadczeniami, podstawa wymiaru jej składek na ubezpieczenie zdrowotne będzie inna niż osób pobierających tylko świadczenie pielęgnacyjne. Pobierana emerytura stanowić bowiem będzie inny tytuł ubezpieczenia w rozumieniu art. 66 ust. 1 pkt 28 u.ś.o.z. W przypadku uznania, że podstawą odpowiadająca wysokości świadczenia pielęgnacyjnego przysługującego na podstawie przepisów o świadczeniach rodzinnych nie jest kwota określona w art. 17 ust. 3 u.ś.r., ale kwota stanowiąca faktyczną wypłatę różnicy między wysokością świadczenia z tego przepisu a emerytura netto, to sytuacja osób pobierajacych pełne świadczenie pielęgnacyjne będzie inna niż tych, które pobierają to świadczenie w wysokości uzupełniającej wysokość emerytury do kwoty świadczenia określonej w ustawie ${ }^{34}$.

W poszukiwaniu uzasadnienia tak wyrażonego zapatrywania WSA w Poznaniu wskazał na brzmienie art. 27 ust. 5 u.ś.r., w którym wskazano, że w przypadku zbiegu uprawnień do świadczenia rodzicielskiego, pielęgnacyjnego, specjalnego zasiłku opiekuńczego, dodatku do zasiłku rodzinnego, o którym mowa w art. 10, lub zasiłku dla opiekuna, o którym mowa w ustawie z 4 kwietnia 2014 r. o ustalaniu i wypłacie zasiłków dla opiekunów - przysługuje jedno z tych świadczeń wybrane przez osobę uprawniona, także gdy świadczenia te przysługują w związku z opieką nad różnymi osobami. Analogiczne zatem osoba, która pobiera emeryturę, powinna dokonać wyboru jednego z tych świadczeń i zrezygnować z pobierania świadczenia niższego - emerytury. Wybór może zostać zrealizowany poprzez złożenie do organu rentowego wniosku o zawieszenie prawa do emerytury na podstawie art. 103 ust. 3 u.e.r.FUS ${ }^{35}$. Zgodnie z tym przepisem prawo do emerytury, renty z tytułu niezdolności do pracy lub renty rodzinnej, do której uprawniona jest jedna osoba, może ulec zawieszeniu również na wniosek emeryta lub rencisty. Zawieszenie prawa do emerytury, zgodnie z art. 134 ust. 1 pkt 1 u.e.r.FUS, skutkować będzie wstrzymaniem wypłaty emerytury, poczynając od miesiąca, w którym została wydana decyzja o wstrzymaniu wypłaty (art. 134 ust. 2 pkt 2 u.e.r.FUS) ${ }^{36}$.

$\mathrm{W}$ orzeczeniach podkreślono jednocześnie, że organy prowadzące postępowanie, realizujacc obowiązek z art. 9 k.p.a., zobowiązane są poinformować o konieczności złożenia wniosku o zawieszenie emerytury i przedstawienia decyzji o wstrzymaniu jej wypłaty. Nadto zgodnie z art. 79a k.p.a. w postępowaniu wszczętym na żądanie strony, informując o możliwości wypowiedzenia się co do zebranych dowodów i materiałów oraz zgłoszonych żądań, organ administracji publicznej jest obowiązany do wskazania przesłanek zależnych od strony, które nie zostały na dzień wysłania informacji spełnione lub wykazane, co może skutkować wydaniem decyzji niezgodnej z żądaniem strony ${ }^{37}$.

${ }^{34}$ Wyrok WSA w Poznaniu z 30 stycznia 2020 r., IV SA/Po 921/19, Lex nr 2799025; wyrok WSA w Poznaniu z 14 listopada 2019 r., II SA/Po 662/19, Lex nr 2745786.

35 Ustawy z 17 grudnia 1998 r. o emeryturach i rentach z Funduszu Ubezpieczeń Społecznych (obecnie t.jedn.: Dz. U. 2020, poz. 53 ze zm. [dalej jako: u.e.r.FUS]).

36 Wyrok WSA w Poznaniu z 30 stycznia 2020 r., II SA/Po 808/19, Lex nr 2779452.

37 Wyrok WSA w Poznaniu z 28 listopada 2019 r., II SA/Po 827/19, Lex nr 2752278; wyrok WSA w Poznaniu z 4 marca 2020 r., II SA/Po 909/19, Lex nr 2837786. 
W wyroku z 24 sierpnia 2020 r. NSA podzielił pogląd WSA w Poznaniu, wskazując, że wypłata świadczenia pielęgnacyjnego w wysokości odpowiadającej różnicy pomiędzy ustawową wysokością tego świadczenia a wysokościa emerytury (netto), niezależnie od trudności co do ustalenia jej podstawy prawnej, spowodowałaby dalsze wątpliwości co do zachowania zasady równości oraz komplikacje w zakresie ustalania przez organ wysokości należnej wypłaty świadczenia w sytuacji otrzymania na przykład trzynastej emerytury, czy też w zakresie odprowadzanych składek na ubezpieczenie zdrowotne i ubezpieczenie emerytalno-rentowe ${ }^{38}$.

Pogląd ten poddany został również krytyce. Wojciech Maciejko stwierdził, że emerytura i świadczenie pielęgnacyjne są prawami konkurencyjnymi, a zatem powinny być przyznawane alternatywnie. Zwrócił jednak uwagę, że zawieszenie prawa do emerytury nie powoduje, że prawo to przestaje przysługiwać, a osoba może nabyć świadczenie pielęgnacyjne. Zdaniem autora należy odróżnić pojęcie sfera przysługiwania prawa do emerytury od sfera wykonywania tego prawa przez realizację wypłat ${ }^{39}$. Podobnie, zdaniem WSA w Gorzowie Wielkopolskim, nieuprawniony jest jednak wniosek, że zawieszenie prawa do emerytury oznacza, że określona osoba nie posiada „ustalonego prawa do emerytury" w rozumieniu art. 17 ust. 5 pkt 1 lit. a u.ś.r. ${ }^{40}$

W mojej ocenie przeciw temu rozwiązaniu przemawia fakt, że w praktyce może pojawić się problem, że opiekunowie pobierający emerytury, którzy złożyli wniosek o ich zawieszenie i wstrzymanie wypłaty, przez pewien okres pozostaną bez środków do życia. Świadczenie pielęgnacyjne sprawach wymagajacych rezygnacji z emerytury przysługiwałoby od miesiąca, w którym strona złożyła wniosek wraz z decyzją o wstrzymaniu wypłaty emerytury z powodu zawieszenia prawa do niej. Wobec powyższego istnieje z obawa, czy świadczenie w ogóle zostanie przyznane, a organ przed wezwaniem do złożenia wymaganej dokumentacji nie sprawdziłby bądź błędnie ocenił, czy osoba ta spełnia wszystkie przesłanki do przyznania jej świadczenia, a zatem czy kierowane do strony wezwanie jest celowe. Tym bardziej że wznowienie wypłaty następuje nie wcześniej niż od miesiąca, w którym zgłoszono wniosek o wznowienie wypłaty.

\section{PODSUMOWANIE}

Rozwiązania problemu zależności pomiędzy uprawnieniem do świadczenia pielęgnacyjnego a uprawnieniem do świadczenia emerytalno-rentowego wymagają zmiany i ingerencji ustawodawcy, gdyż sa niedostosowane do zmieniającej się sytuacji ekonomicznej, co w praktyce wywołuje kontrowersje. Brak inicjatywy legislacyjnej w tym zakresie i pozostawienie judykaturze problemu

${ }^{38}$ I OSK 650/20, Lex nr 3048813.

${ }^{39}$ Maciejko (2019): 235.

${ }^{40}$ Wyrok WSA w Gorzowie Wielkopolskim z 19 grudnia 2019 r., II SA/Go 774/19, Lex nr 2759823. 
niedostosowanych uregulowań jest niedopuszczalne w demokratycznym państwie prawa.

Dotychczasowa praktyka wskazuje jednak, że w zależności od składu orzekającego NSA oraz dany wojewódzki sąd administracyjny na przestrzeni jedynie kilku miesięcy w podobnym stanie faktycznym wydają wyroki przyjmujące odmienną wykładnię wskazanego przepisu. Sądy niejako przejmuja rolę ustawodawcy, dostosowując prawo w konkretnej sprawie w celu wydania słusznego i sprawiedliwego wyroku. Przedstawiona rozbieżność orzecznicza obrazuje brak odpowiedniego zabezpieczenia w Polsce osób niepełnosprawnych i ich opiekunów.

Ustawodawca winien jednoznacznie uregulować niniejsze zagadnienie przez dopuszczenie możliwość przyznania świadczenia pielęgnacyjnego osobie mającej ustalone prawo do emerytury w wysokości niższej niż to świadczenie albo wprowadzenie sprawnej możliwości świadczeniobiorcom wyboru świadczenia, jeśli wystapi ich zbieg.

W mojej ocenie nie można zgodzić się z rozwiązaniem, które pozbawia w całości prawa do świadczenia pielęgnacyjnego osoby mające ustalone prawo do emerytury (renty) w wysokości niższej niż to świadczenie. Mając na uwadze, wspomniane ryzyko, że opiekunowie pobierajacy emerytury, którzy złożyli wniosek o ich zawieszenie i wstrzymanie wypłaty, pozostana przez pewien okres bez środków do życia, opowiedzieć należy się za rozwiązaniem przyznania świadczenia pielęgnacyjnego w wysokości pomniejszonej o emeryturę faktycznie otrzymywana, tj. w tzw. wysokości netto (pomniejszonej o zaliczkę na podatek dochodowy od osób fizycznych oraz składkę na ubezpieczenie zdrowotne).

Bartoszewicz, M. (2014). Komentarz do art. 146-162, [w:] M. Haczkowska (red.) Konstytucja Rzeczypospolitej Polskiej. Komentarz. Warszawa: 48-218.

Garlicki, L. (2002). Polskie prawo konstytucyjne. Zarys wykładu. Warszawa.

Gutowski, M., Kardas, P. (2017). Wykładnia i stosowanie prawa w procesie opartym na Konstytucji. Warszawa.

Kawecka, A., Małysa-Sulińska, K., Sapeta, J. (2015). Komentarz do art. 17, [w:] K. Małysa-Sulińska (red.), Ustawa o świadczeniach rodzinnych. Warszawa: Lex/el.

Kondej, M. (2019). Przełamanie rezultatów wykładni językowej zgodnie z zasadą nadrzędności Konstytucji. Ruch Prawniczy, Ekonomiczny i Socjologiczny 81(3): 39-52.

Kopania, R. (2017). Komentarz do art. 17, [w:] R. Kopania (red.), Świadczenia rodzinne. Świadczenia dla opiekunów. Komentarz. Legalis.

Lewandowicz-Machnikowska, M. (2019). Zbieg prawa do świadczeń opiekuńczych i świadczeń z ubezpieczenia społecznego - uwagi de lege ferenda. Przegląd Prawa i Administracji 117: $37-46$.

Maciejko, W. (2019). Komentarz do art. 17, [w:] W. Maciejko (red.), Świadczenia rodzinne. Komentarz. Warszawa: 233-239.

Masternak-Kubiak, M. (2002). Prawo do równego traktowania, [w:] B. Banaszak, A. Preisner (red.), Prawa i wolności obywatelskie w Konstytucji RP. Warszawa.

Morawski, L. (2002). Wykładnia prawa w orzecznictwie sądów. Komentarz. Toruń.

Morawski, L. (2010). Zasady wykładni prawa. Toruń.

Mrozek, P. (2017). Świadczenia rodzinne. Procedury i zasady przyznawania prawa do świadczeń rodzinnych w praktyce. Warszawa.

Płeszka, K. (1997). Językowe znaczenie tekstu prawnego jako granica wykładni, [w:] M. Zirk-Sadowski (red.), Sześć lat Konstytucji Rzeczypospolitej Polskiej. Doświadczenia i inspiracje. Łódź: 69-77. 
Preisner, A. (2003). Dookoła Wojtek. Jeszcze o bezpośrednim stosowaniu konstytucji RP, [w:] L. Garlicki, A. Szmyt (red.), Sześć lat Konstytucji Rzeczypospolitej Polskiej. Doświadczenia i inspiracje. Warszawa: 230-244.

Rozbicka-Ostrowska, M. (2015). Komentarz do spraw o świadczenia rodzinne, [w:] J. Ignaczewski (red.), Komentarz do spraw administracyjnych. Wybrane zagadnienia. Warszawa.

Sierpowska, I. (2004) Kryteria ustalania uprawnień do świadczeń rodzinnych. Monitor Prawa Pracy 6: 162-165.

Ślebzak, K. (2016), [w:] M. Safjan, L. Bosek (red.), Konstytucja RP. Tom 1: Komentarz do art. 1-86. Warszawa: 1457-1724.

Tarno, J. (2016). Zasada równości stron, [w:] R. Hauser (red.), System prawa administracyjnego. Tom 10: Sądowa kontrola administracji publicznej. Warszawa: 220-221.

Wincenciak, M. (2018). O respektowaniu zasad prawa na przykładzie świadczeń opiekuńczych, [w:] Z. Duniewska, A. Krakała, M. Stahl (red.), Zasady w prawie administracyjnym. Teoria, praktyka, orzecznictwo. Warszawa: 294-304.

Zieliński, M. (2009). Wybrane zagadnienia wykładni prawa. Państwo i Prawo 64(6): 3-10.

Zieliński, M. (2017). Wykładnia prawa. Zasady - reguły - wskazówki. Warszawa.

\section{THE IMPACT OF THE RIGHT TO RETIREMENT ON THE RIGHT TO NURSING BENEFIT: DISPUTES AND CONTROVERSIES}

\section{Sum mary}

The article analyses the issue of granting a nursing benefit to a person who has a fixed pension entitlement. The topic is important because it concerns providing material support to people who resign from professional activity to look after a disabled person. Recent discrepancies in the jurisprudence of administrative courts do not allow for an unequivocal assessment of the impact of the established right to a pension on the possibility of acquiring the right to a nursing benefit. Within the same administrative court, different adjudication panels have different views, which does not give citizens a sense of legal certainty. The author analysed the presented views in the case-law and pointed out the possibilities of solving the problem. In the author's opinion, the legislator does not take into account the changing economic and social situation in the adopted solutions of the relationship between the entitlement to nursing benefit and the entitlement to a retirement pension, which causes controversy in practice. The lack of a legislative initiative in this area means that the courts begin to correct unadjusted provisions in order to issue fair rulings.

Keywords: social assistance; disabled person; care benefits; person providing care; nursing benefit; retirement pension 